\title{
Distinct Element Simulation of a Landslide Process
}

\author{
Lesław Zabuski, Jacek Mierczyński \\ Institute of Hydro-Engineering, Polish Academy of Sciences, 7 Kościerska, 80-328 Gdańsk, Poland, \\ e-mail: leslawzabuski@ibwpan.gda.pl
}

(Received June 10, 2020; revised November 10, 2020)

\begin{abstract}
The paper presents a numerical simulation of the development of a catastrophic landslide in a sandstone quarry and methods of reconstructing the quarry to its previous condition from before the landslide. The important objective of the paper is to present the capabilities of the numerical method used in the analysis of the landslide process, namely the Distinct Element Method (DEM). This method is poorly known, though it is capable of solving important geotechnical problems in which massive displacements are modelled. The features of the method are presented on the basis of a case study. Therefore a numerical analysis is carried out to show the performance of DEM in generating a displacement of several dozen meters in the example of a catastrophic landslide that occurred some years ago in a sandstone quarry. This engineering problem makes it possible to describe and analyse the mechanisms, causes and consequences of the landslide.
\end{abstract}

Key words: Distinct Element Method, sandstone quarry, landslide

\section{Introduction}

The paper presents a numerical simulation of the development of a catastrophic landslide in a sandstone quarry and methods of reconstructing the quarry to its previous condition. In the process, the paper also presents the capabilities of the Distinct Element Method (DEM). This method is poorly known, though it is capable of solving important geotechnical problems in which massive displacements are modelled. (Itasca 2004).

The quarry is located about $70 \mathrm{~km}$ south of Cracow in the Polish Carpathians, the rock mass is built of a flysch formation, composed mainly of sandstone and clay shale in different proportions (Zabuski 2019, Bober et al 1997, Bober and Zabuski 1993, Zabuski et al 2009). In the surroundings of the quarry, thick-bedded muscovite sandstone dominates (Fig. 1), which is exploited and used for construction of roads.

(C) 2020 Institute of Hydro-Engineering of the Polish Academy of Sciences. This is an open access article licensed under the Creative Commons Attribution-NonCommercial-NoDerivs License (http://creativecommons.org/licenses/by-nc-nd/4.0/). 


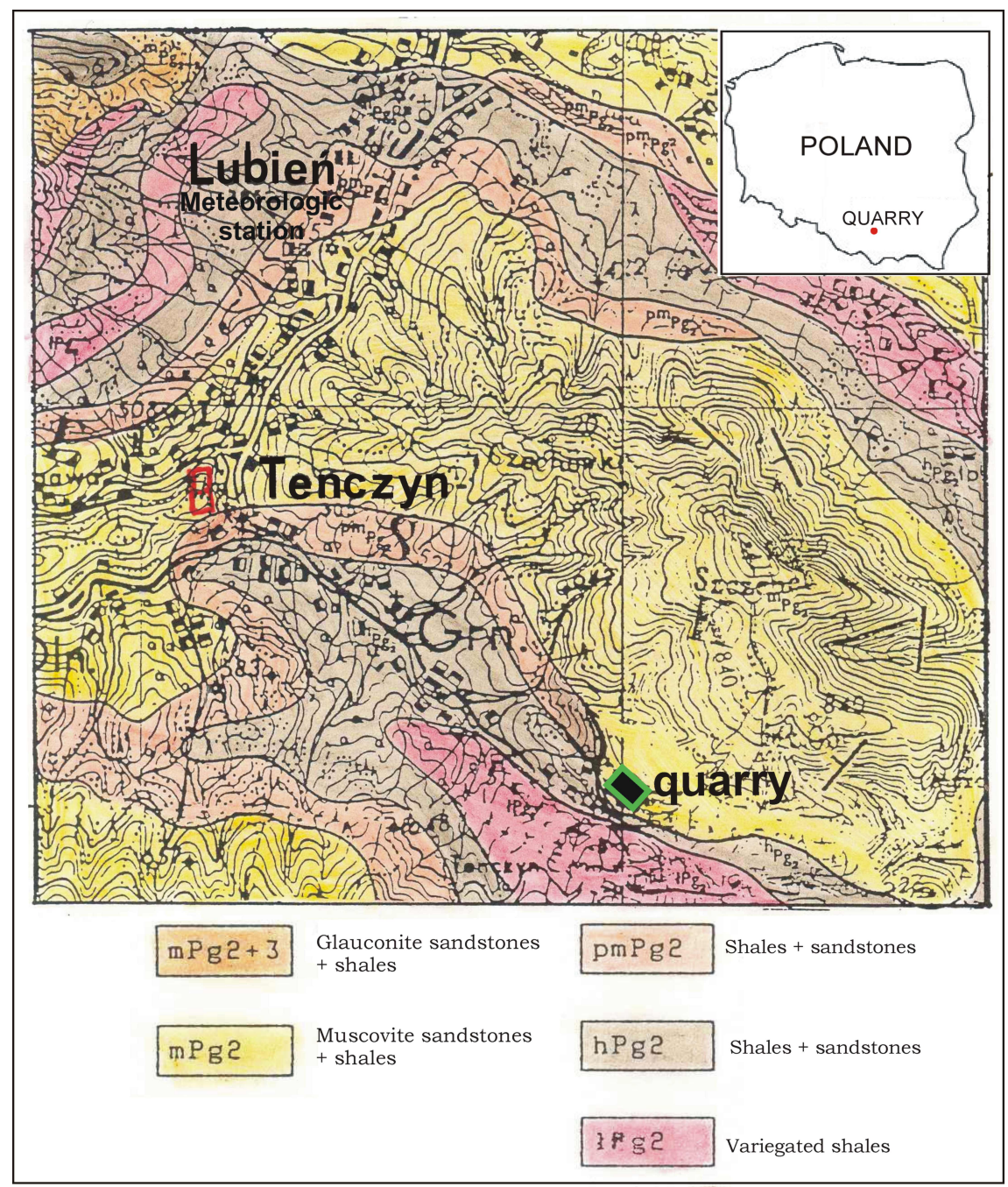

Fig. 1. Geology of the neighbourhood of the quarry (after Borysławski et al 1981; supplemented and modified)

The extraction of the sandstone is performed by the standard method, in which explosives are used. In the uppermost part of the quarry, the sandstone deposit is covered by a few-meter-thick Quaternary overburden composed of sand and gravel.

In early September 2007, rainfalls were extremely intensive in the south of Poland, triggering floods and landslides. At the same time, the Quaternary soil cover slid down, together with the underlying sandstone blocks. The mining was stopped, and the following questions were raised:

- How serious is the loosening of sandstone below the moving overburden?

- Is further mining possible, and can it be safe?

- What countermeasures should be taken to avoid further damage? 
The main objective of this paper is to answer the above questions. For this purpose, a numerical analysis was carried out to simulate the phenomena that are visible on the surface or occur in the sandstone under the sliding cover. The influence of water was also considered in the simulation. The numerical code UDEC 2D (Itasca 2004) based on the distinct element method (Starfield and Cundall 1988, Giani 1992, Zabuski and Marcato 2014, Cundall and Hart 1993) was used in the analysis, which makes it possible to simulate the process of deformation of discontinuous media. The rock mass was modelled as a set of solid rock blocks interacting along discontinuities. It has to be underlined that discontinuities play a fundamental role in the development of deformation processes in rock masses (Hoek and Bray 1981). Discontinuous modelling is appropriate, above all, in the case of hard rocks (Marcato et al 2005, 2007, Zabuski and Marcato 2014). However, in the present example, the soil mass was also divided into blocks. It can be assumed that in this approach such an approximation is sufficiently accurate provided that the soil blocks are small. The geotechnical parameters of the rock and soil layers were unknown, so they were determined using the back analysis procedure.

\section{Causes of the Landslide Development}

\subsection{General Remarks}

The landslide developed on September 6, 2007, during a period of extremely high rainfall, equal to about $230 \mathrm{~mm}$, which caused a significant saturation of the soil overburden covering the sandstone deposit (Fig. 2). The mean annual precipitation in this

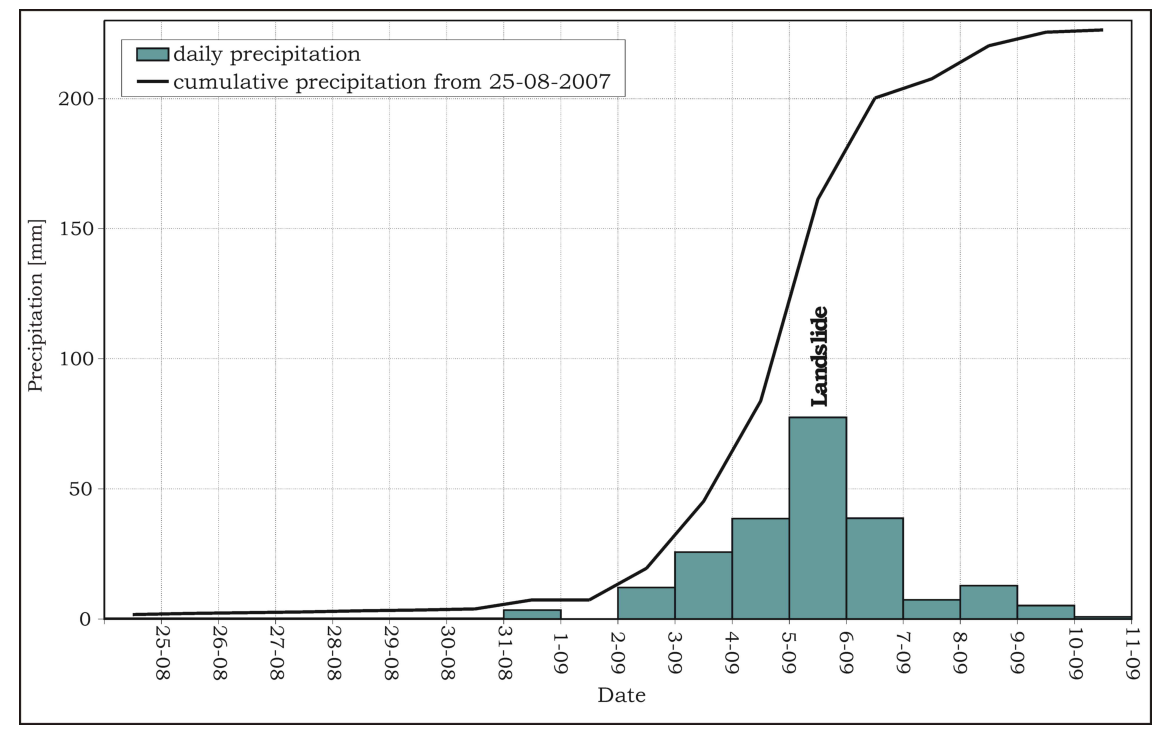

Fig. 2. Level of precipitation at the time of the landslide; measured at a meteorological station ca $10 \mathrm{~km}$ from the quarry 


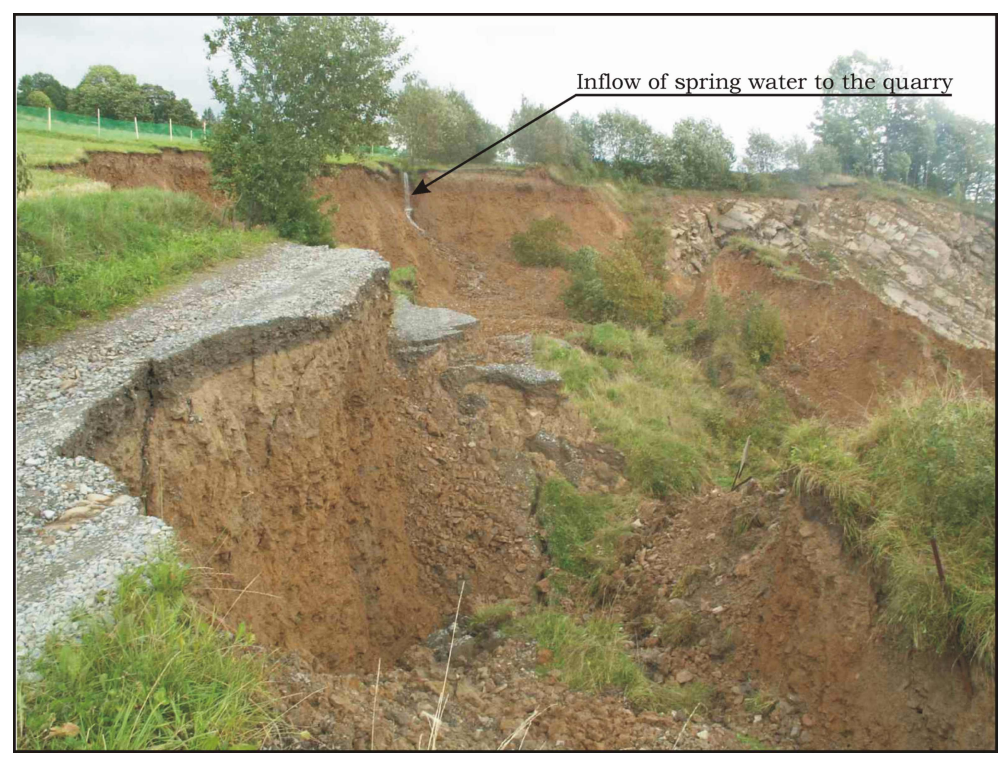

Fig. 3. Region of the landslide main scarp. An inflow of water from a spring into the landslide area can be seen

region is about $900 \mathrm{~mm}$, which means that almost $25 \%$ of this amount fell during only 5 days. The soil was additionally saturated by springs originating in the upper part of the slope, above the quarry (Fig. 3). These two factors had a strong effect on the deterioration of the soil quality, i.e. its weakening and probably scouring. The soil practically lost its strength, turning into fluid. It is also probable that a continuous ground water table (GWT) was created, generating high hydrostatic pressure in fractures between the sandstone blocks that underlie the soil cover.

The above-mentioned premises are the starting point for the numerical analysis, which aims to simulate the slide and reconstruct phenomena occurring in the sandstone.

\subsection{Numerical Simulation of the Landslide}

\section{Computer program and numerical model}

The UDEC code is based on the distinct element method which makes it possible to simulate a displacement in a two-dimensional model composed of continuous rock or soil blocks, touching one another along the so-called "interfaces", which imitate natural or artificial fractures. The principles of the method were elaborated by P. Cundall (1971). The properties of the method make it especially useful in the analysis of discontinuous media. It is possible to take into account the heterogeneities of the medium (rock mass), complex configurations of the discontinuities, non-linear behaviour of both the intact rock and discontinuities, and water flow through discontinuities. 


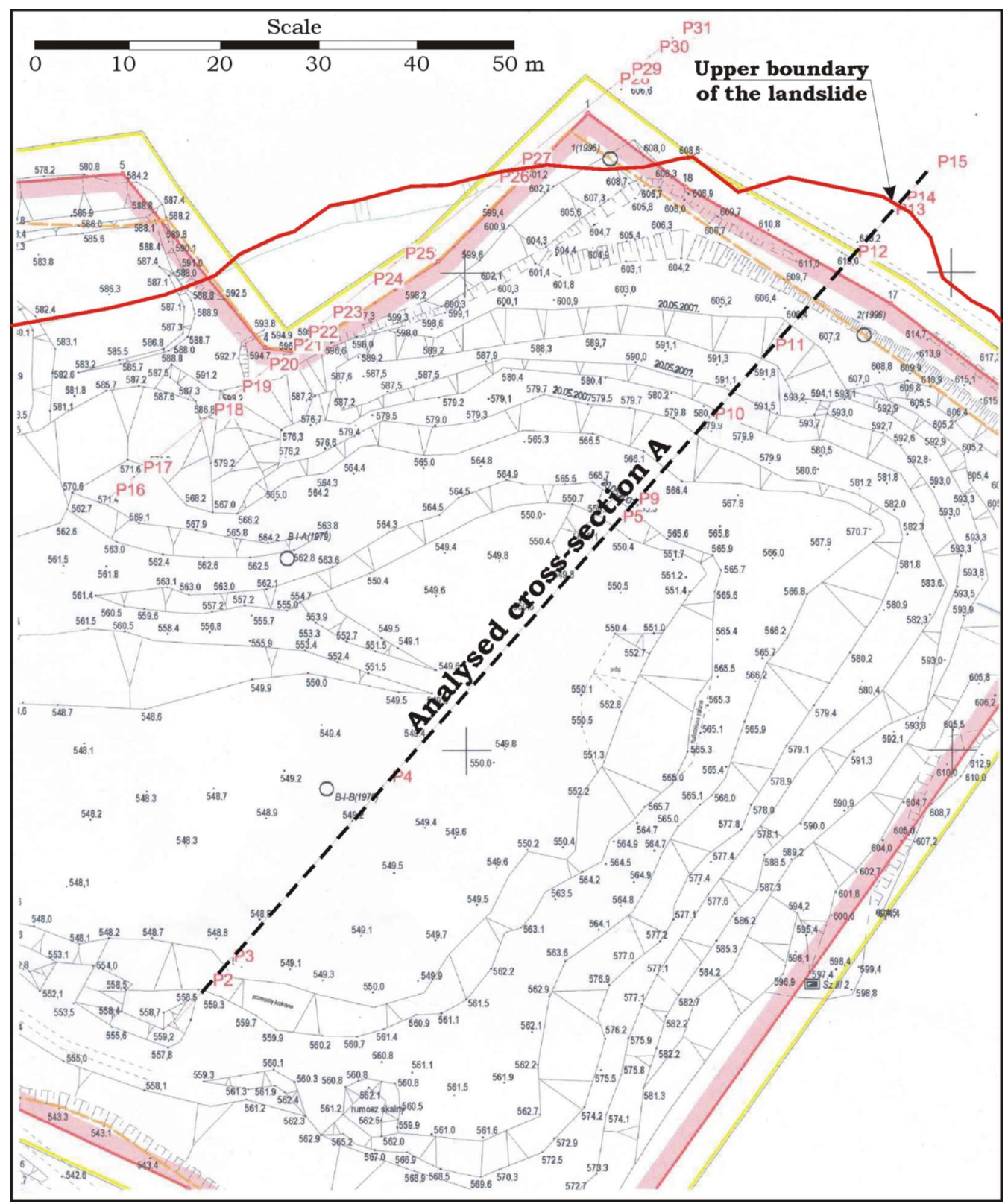

Fig. 4. Schematic map of the quarry (on May 20, 2007, i.e. before landslide) with the cross-section "A"

The location of the analysed cross-section "A" is shown on the map of the quarry in Fig. 4. The geomechanical model for the cross-section "A" with divisions of the analysed space into layers of different kind and quality is presented in Fig. 5. This division was carried out on the base of the observation of the disintegration of the rock 


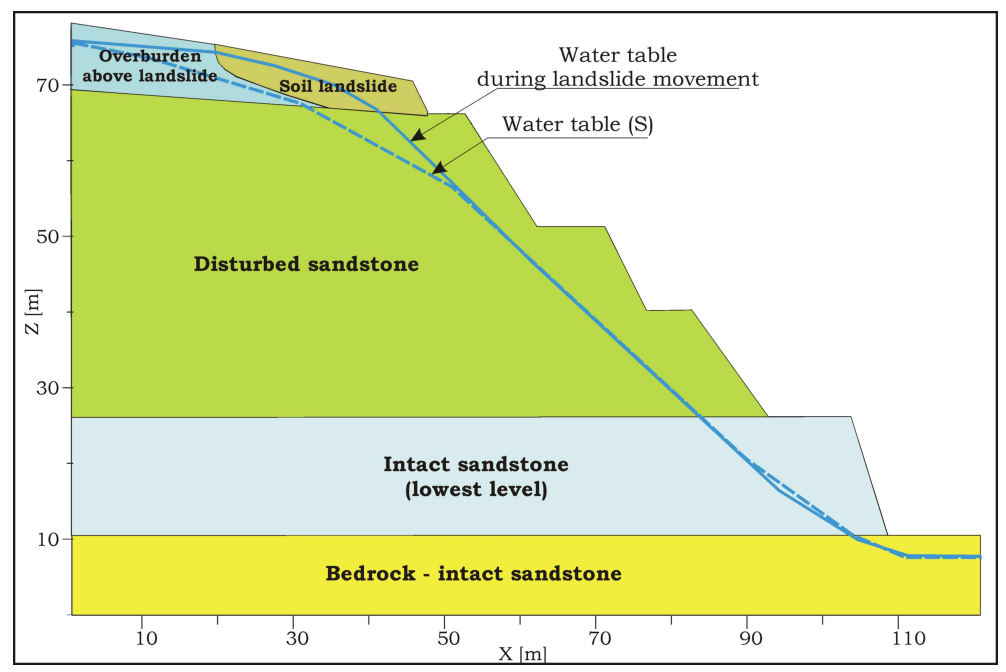

Fig. 5. Model of the slope with two curves marking the position of the Ground Water Table (GWT)

mass composing the whole slope. Two curves of GWT are drawn in the figure. One of them, marked by dotted line, represents relatively favourable, "average" hydrological conditions, whereas the other (continuous line) shows the water table at the time of the landslide. As already mentioned, GWT suddenly rose during the heavy rainfall period, and the soil became fully saturated, which was the principal cause of the landslide development.

Figure 6 presents a numerical model composed of continuous blocks. The dimensions of sandstone block are $2 \times 2 \mathrm{~m}$ (i.e. 4 sq.m). The soil body was artificially divided into small blocks with dimensions of $0.5 \times 0.5 \mathrm{~m}$ (i.e. 0.25 sq.m). Thanks to this division, it can be assumed that the soil is imitated properly as an assemblage of blocks. In the present case, the blocks are non-deformable (rigid). Therefore the deformation processes, both sliding and widening triggered by tension, can occur only in the interfaces between them. The geomechanical parameters of the interfaces are shown in Table 1. In fact, these parameters were unknown, so they were determined using a back analysis procedure. The correctness of parameters was checked by a trial and error procedure - the parameters were changed iteratively until the initiation of the landslide and its continuous movement occurred.

\subsection{Results of Numerical Simulation}

The slope is stable in the case of the lower ("S") GWT (see Fig. 5), and an equilibrium is reached after small displacements (Fig. 7). However, it is supposed that the water fluctuated in the past, and some signs of failure, such as open cracks, were visible even earlier. Thus, the analysed landslide can be considered as an ultimate stage of failure. 


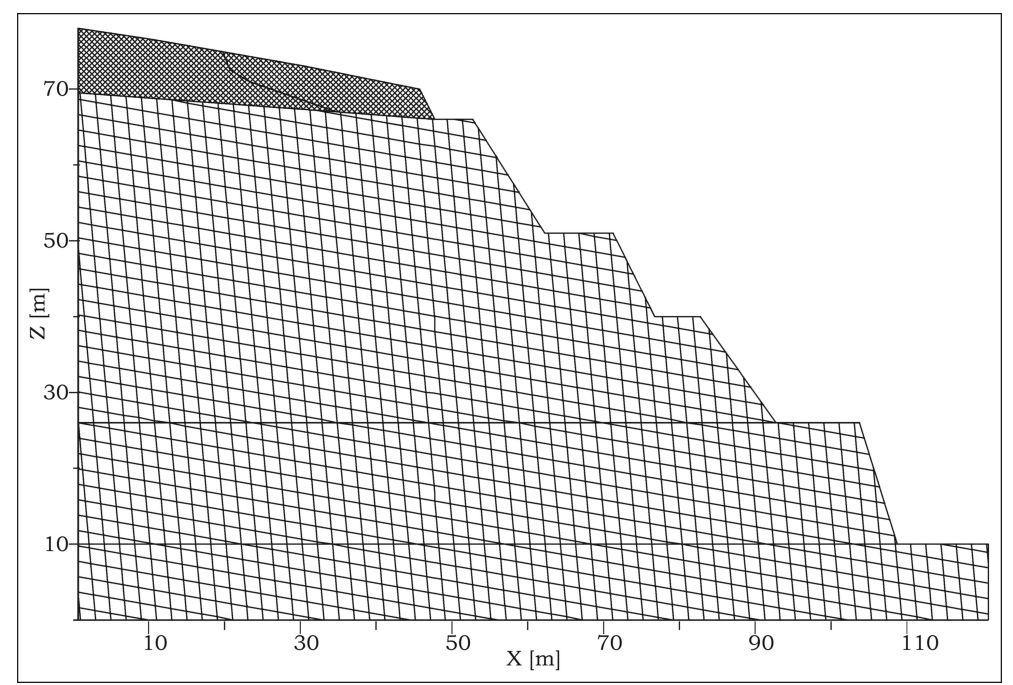

Fig. 6. The mass split into continuous blocks

Table 1. Geomechanical parameters of interfaces

\begin{tabular}{|c|c|c|c|c|c|}
\hline Layer & $\begin{array}{c}\text { Shear } \\
\text { stiffness } \\
{[\mathrm{kN} / \mathrm{m}]}\end{array}$ & $\begin{array}{c}\text { Normal } \\
\text { stiffness } \\
{[\mathrm{kN} / \mathrm{m}]}\end{array}$ & $\begin{array}{c}\text { Cohesion } \\
{[\mathrm{kPa}]}\end{array}$ & $\begin{array}{c}\text { Angle of } \\
\text { friction } \\
{\left[^{\circ}\right]}\end{array}$ & $\begin{array}{c}\text { Tension } \\
\text { strength } \\
{[\mathrm{kPa}]}\end{array}$ \\
\hline Bedrock & $2.5 \mathrm{E}+7$ & $2.5 \mathrm{E}+7$ & 500 & 45 & \multirow{5}{*}{0.0} \\
\hline Intact sandstone & $2.5 \mathrm{E}+7$ & $2.5 \mathrm{E}+7$ & 100 & 40 & \\
\hline Disturbed sandstone & $2.5 \mathrm{E}+6$ & $3.0 \mathrm{E}+6$ & 25 & 35 & \\
\hline Sliding soil & $5.0 \mathrm{E}+4$ & $5.0 \mathrm{E}+4$ & 0 & 5 & \\
\hline Soil above the landslide & $2.5 \mathrm{E}+6$ & $2.5 \mathrm{E}+6$ & 20 & 30 & \\
\hline
\end{tabular}

A rise in the GWT during the first days of September caused sudden deformations, and the final effect was an extensive slide. As a roof of loosened sandstone was uncovered by the sliding soil, water infiltrated easily into this mass, and the GWT dropped rapidly. In consequence, the situation after the landslide became stable.

In the next period and the calculation trial, the GWT rose to the level shown by the continuous line in Fig. 5. The soil started to move from its initial position, and large displacements occurred. Two states of failure are shown in Fig. 8: the intermediate and the final one. It should be underlined that the latter state is very similar to the appearance of the sandstone walls.

With regard to the possibility of sandstone mining in the future, an important problem was the unknown quality and condition of this deposit. It is highly probable that the rock blocks were separated due to water pressure, and the entire mass was significantly loosened. Moreover, moving soil fell into empty spaces and filled opened fractures between sandstone blocks, which is shown in Fig. 9. This problem cannot be evaluated reliably, as the parameters of the interfaces can be only approx- 


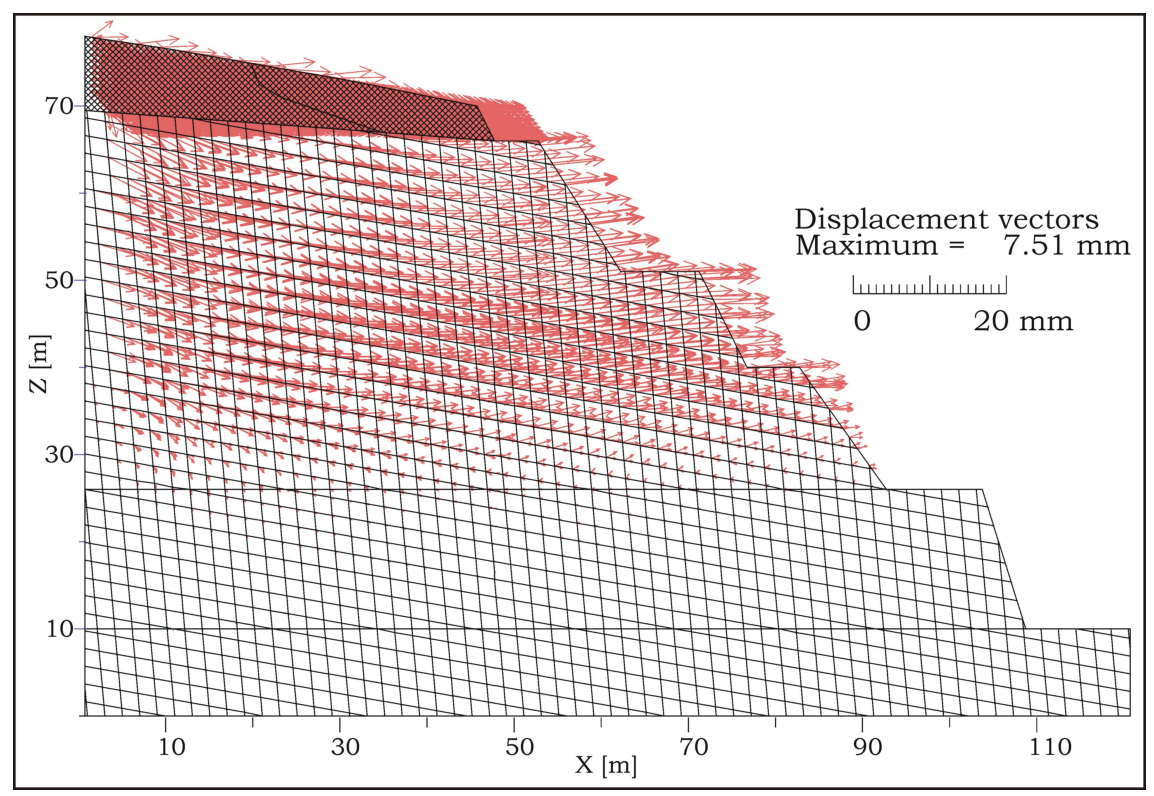

Fig. 7. Displacement vectors - the model under dry conditions, a low ground water table and a stable state of the slope

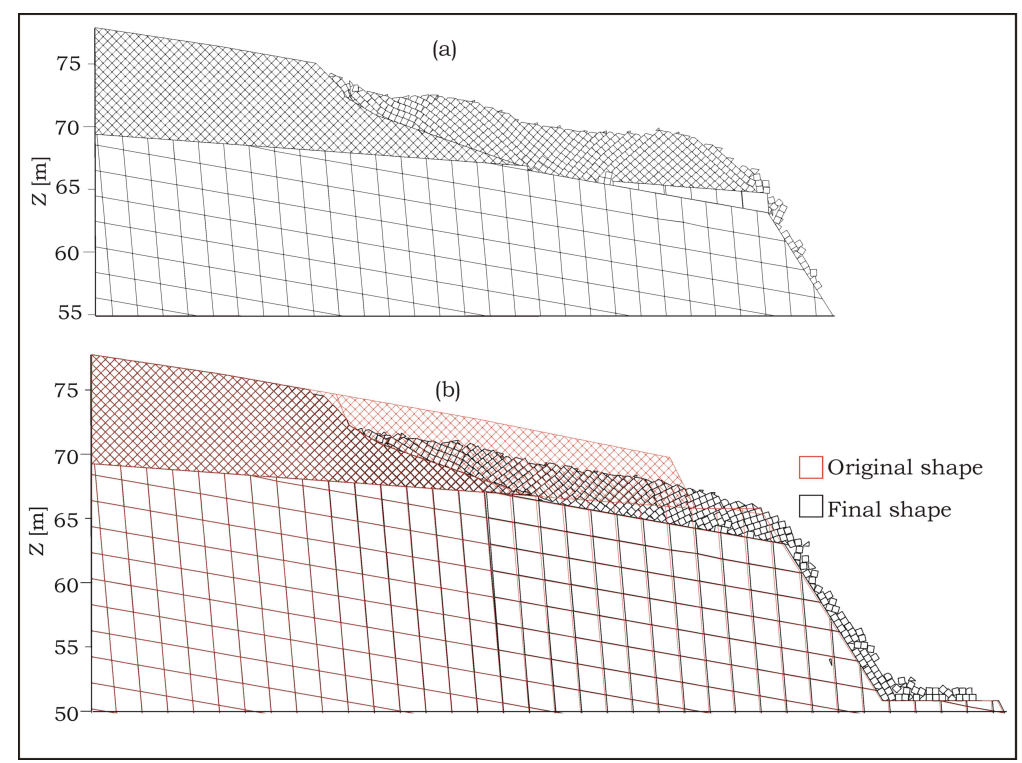

Fig. 8. Two states of the landslide process; (a) intermediate state, (b) final state

imated, and even a small decrease in their values results in a significant opening of the fractures and loosening of the sandstone. Such a situation is shown in Fig. 10 for a decrease in normal stiffness of the disturbed sandstone to $2.5 \mathrm{E}+6 \mathrm{kN} / \mathrm{m}$ (instead of 
$3.0 \mathrm{E}+6 \mathrm{kN} / \mathrm{m}$ - see Table 1). The fracture is wide open, and loosening is very intensive. It can thus be said that the numerical simulation indicates certain mechanisms only qualitatively.

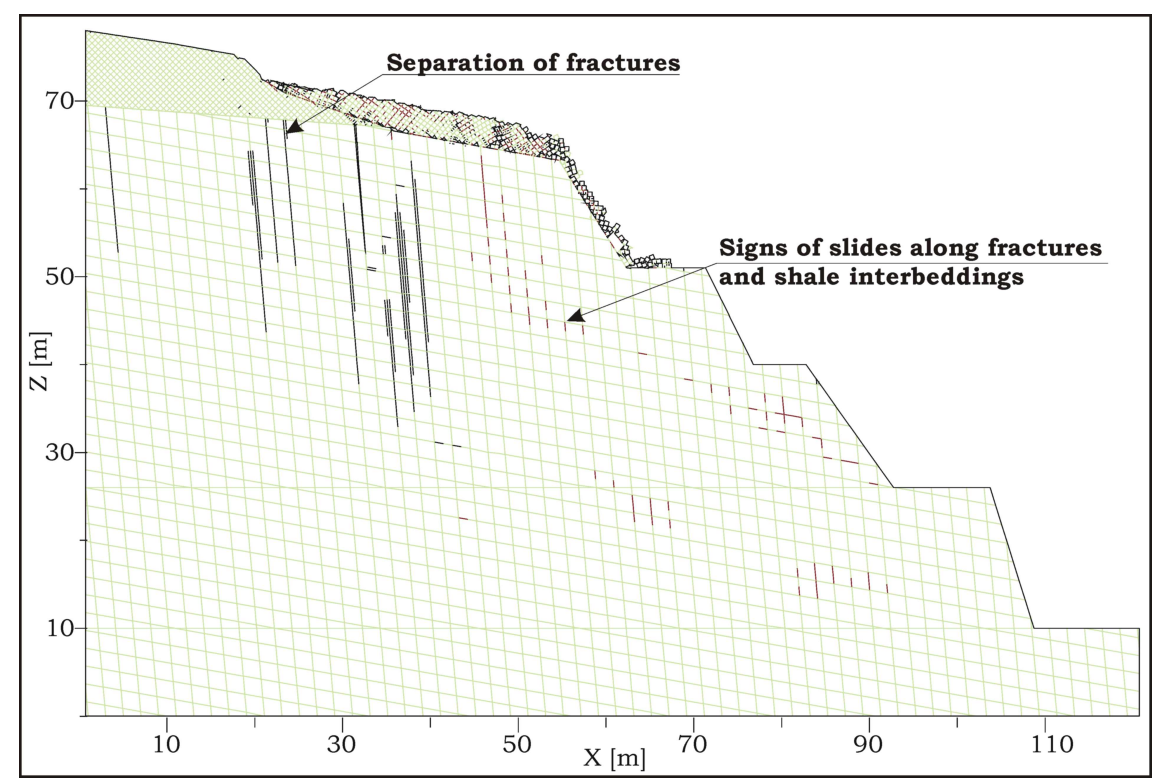

Fig. 9. Separation and slide along fractures in the sandstone mass

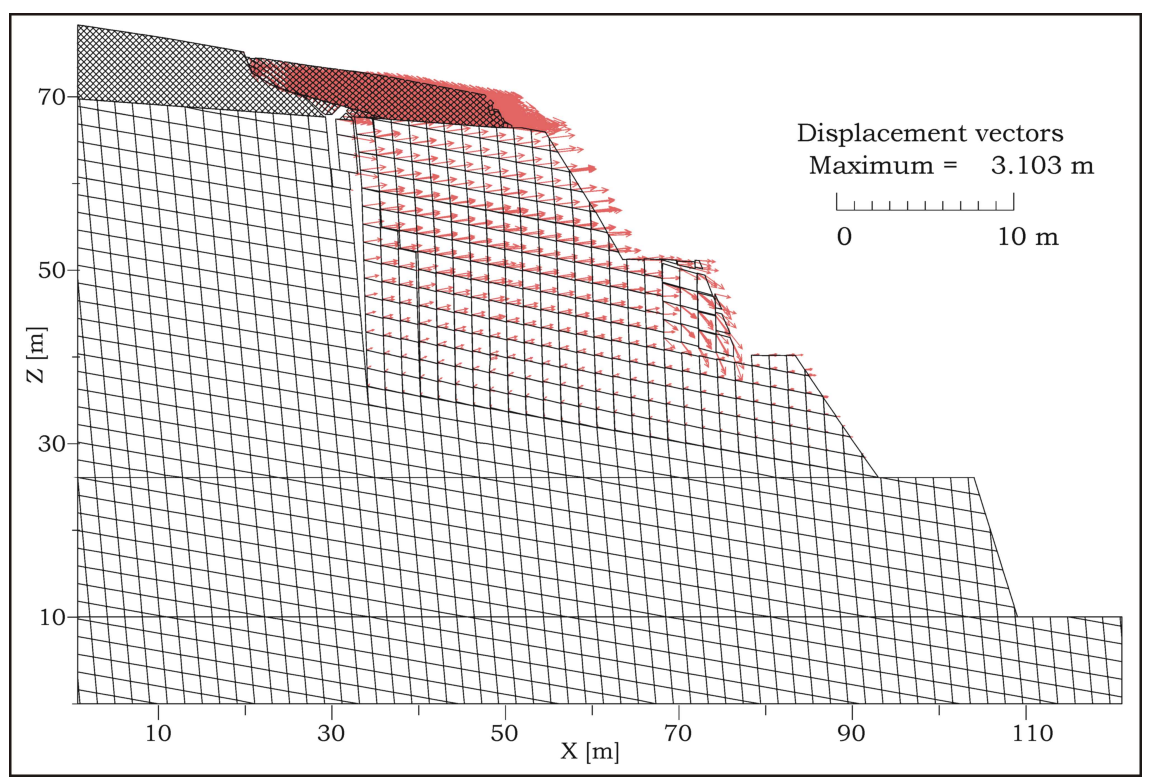

Fig. 10. Probable opening of fractures in the sandstone mass 


\section{Proposals for Stabilisation and Reconstruction}

\section{Regulation of water conditions}

Since the main or even the only cause of the landslide development was water action, it was first necessary to stop water inflow into the quarry. A system of superficial and underground draining ditches was proposed to stop the inflow of water from springs and to limit the run-off from rainfall. A designed system is presented in Fig. 11. The superficial drains are lined with concrete forms. The underground drainage, shown in Fig. 12, is built in a typical way,. The drain is composed of perforated pipe surrounded by granular soil, and the ditch is inlayed with geotextile. In addition, and very importantly, open cracks are sealed with impermeable soil, e.g. clay or loam, which prevents the penetration of water through the cracks into the sandstone mass.

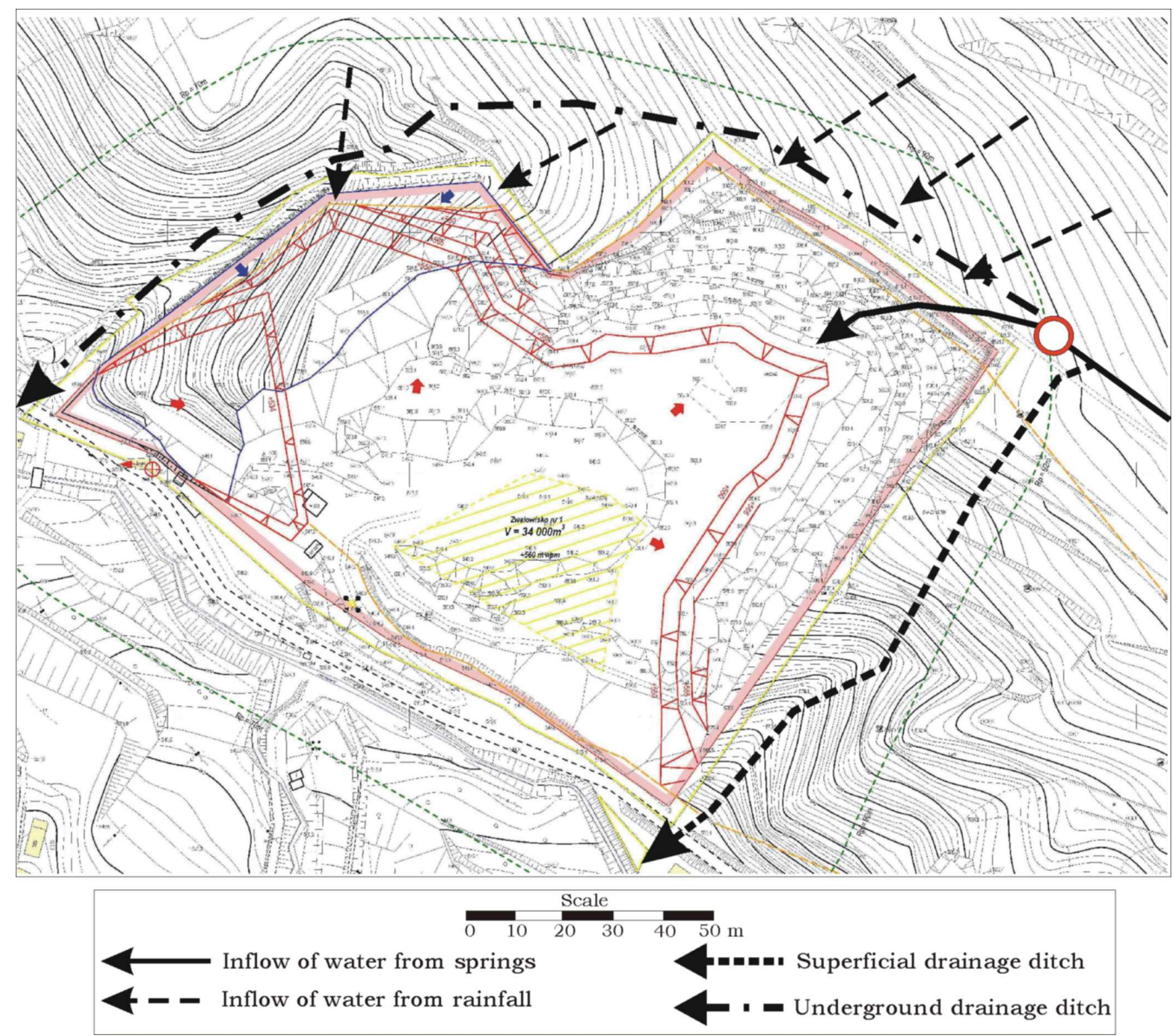

Fig. 11. Scheme of water inflow and drainage works around the quarry 


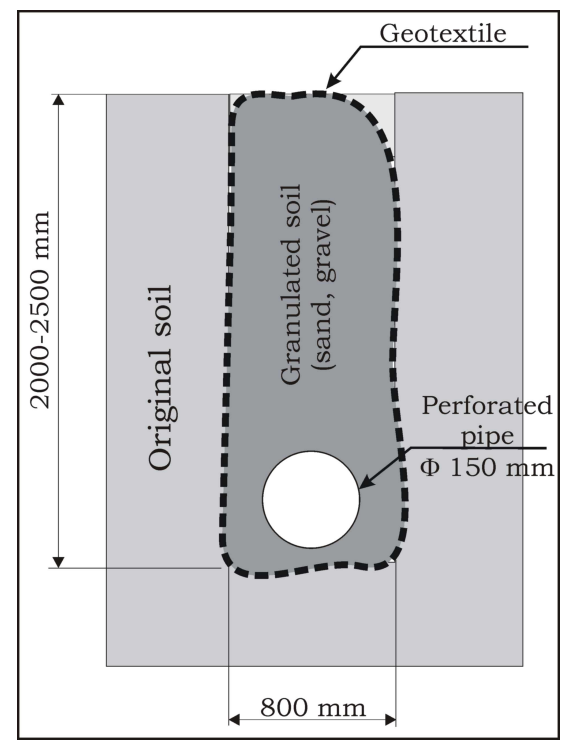

Fig. 12. Underground drain

\section{Change of the inclination of the landslide main scarp}

The steep inclination of the main scarp wall (see Fig. 3) causes a retrogressive failure of the slope above the main scarp of the landslide. It was therefore suggested that this inclination be decreased (Fig. 13). No sophisticated structures are necessary; only grass should be sown on the slightly inclined surface. The soil from the area below the scarp will also be removed, which will have the positive effect of unloading the sandstone deposit. All earth works should be started at the uppermost place and proceed downwards.

\section{Numerical simulation of the behaviour of the model after introduction of countermeasures}

The numerical simulation was repeated after the introduction of above modifications into the model. The results, in the form of displacement vectors, are presented in Fig. 14. Some displacement in the direction opposite to the open space was generated, which proves that the formerly open cracks were closed. The model reached equilibrium within a short time.

\section{Final Remarks}

Three questions were formulated in the introduction to this paper, and the results obtained provide the answers. It was proven that sandstone below the soil slide is loosened due to the opening of fractures. Further mining of the rock in the quarry was still possible, although special attention has to be paid during exploitation as the 


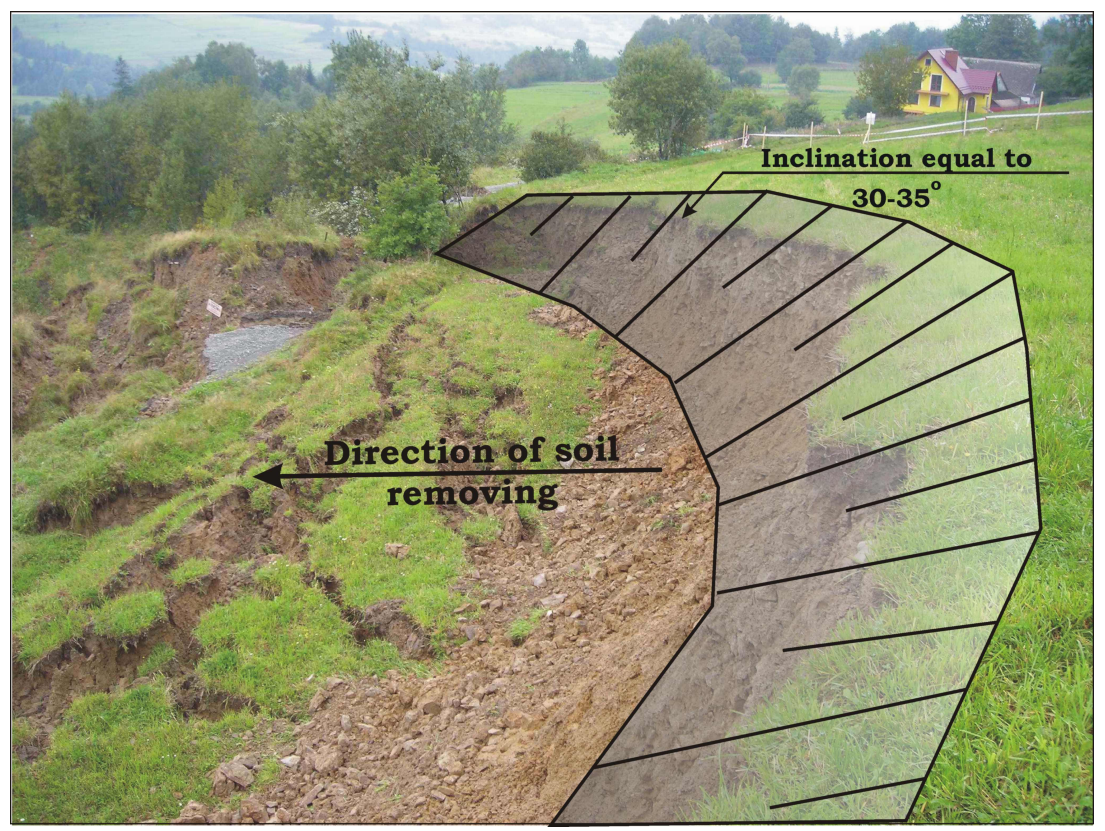

Fig. 13. Proposed earth works in the region of the main scarp of the landslide

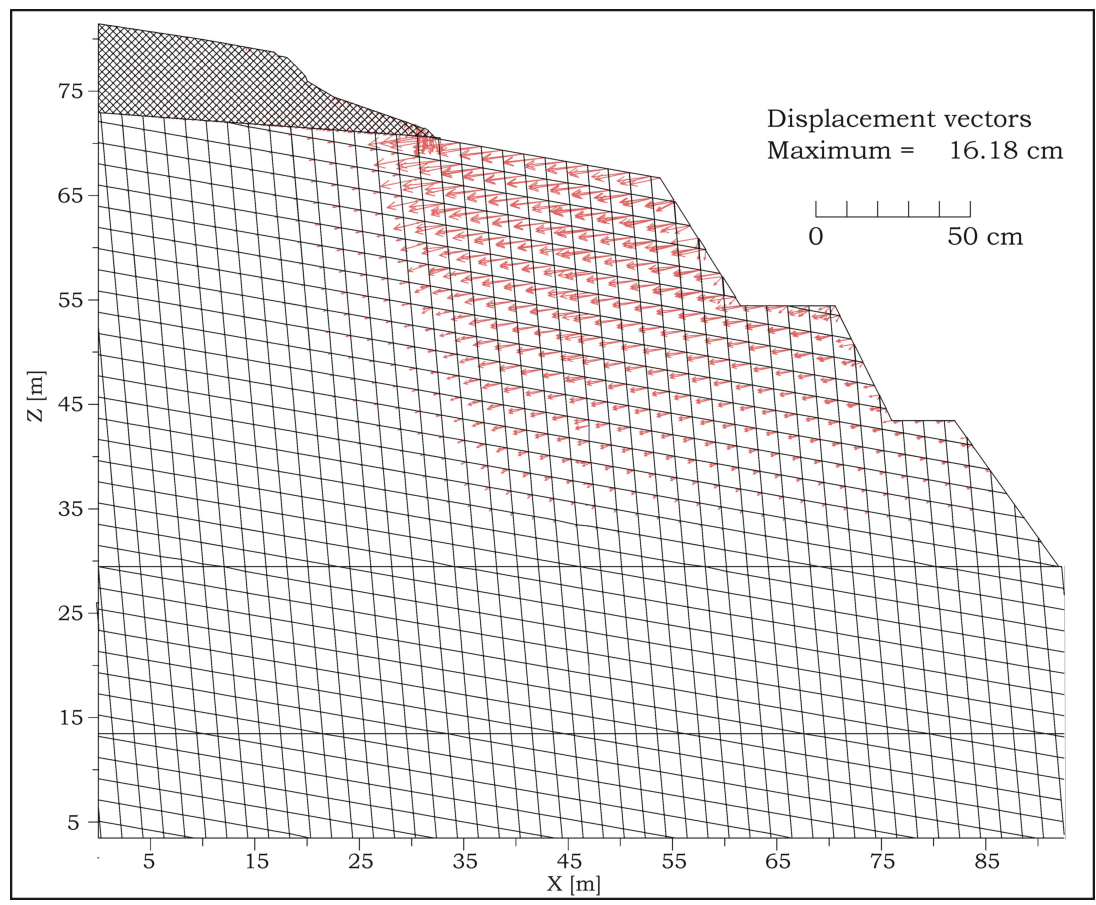

Fig. 14. Displacement vectors in the quarry after repair and stabilisation works 
loosened blocks may fall, causing danger. The suggested countermeasures are not sophisticated. Since the main cause of the landslide was water inflow, closing the path of this inflow and decreasing the amount of water will be beneficial. It can be said that it will help prevent further instability under the condition that the drainage system works properly, without any disturbances.

This paper also shows a possible method of solving rock and soil mass deformation problems by modelling the medium as discontinuous, especially by the Distinct Element Method. This approach can undoubtedly be correctly applied in cases of hard rocks divided into solid blocks, such as sandstone or similar. It is problematic in the case of soil, but the results of the present analysis show that the approximation of the soil mass as a set of blocks is sufficiently accurate and satisfactory provided that the blocks are small. Discontinuous modelling makes it possible to simulate very large displacements, and it could be considered as one of main advantages of this approach.

\section{References}

Bober L., Zabuski L. (1993) Flysch Slope Classification from Viewpoint of the Landslide Prediction, Proc. Int. Symp. "Geotechnical Engineering of Hard Soils-Soft Rocks", Athens 1993, A.A. Balkema, Rotterdam - Brookfield, Vol. 2, 1065-1072.

Bober L., Thiel K., Zabuski L. (1997) Landslide Phenomena in the Polish Carpathian Flysch: Geological and Engineering Properties of Selected Landslides, IBW PAN, Gdansk (in Polish).

Borysławski A., Burtan J., Golonka J., Oszczypko N., Paul Z., Ślączka A., Ryłko W. (1981) Section of Geologic Map of Poland elaborated in 1979, Wydawnictwa Geologiczne, Warszawa.

Cundall P. (1971) A Computer Model for Simulating Progressive Large Movements in Blocky Rock Systems, łProc. Symp. ISRM, Nancy, Vol. I, pap. II-8.

Cundall P., Hart R. D. (1993) Numerical Modelling of Discontinua, [in:] J. A. Hudson, ed., Comprehensive Rock Engineering, Pergamon Press, Oxford-NY-Seoul-Tokyo, Vol. 2, 231-261.

Giani G. P. (1992) Rock Slope Stability Analysis, A.A. Balkema, Rotterdam/Brookfield.

Hoek E., Bray J. D. (1981) Rock Slope Engineering, 3rd edition. Taylor \& Francis Group., London, New York.

Itasca Consulting Group, Inc. (2004) UDEC Manual, Itasca Consulting Group Inc.

Marcato G., Silvano S., Zabuski L. (2005) Modellazione di ammassi rocciosi instabili con il metodo degli elementi distinti, Giornale do Geologia Applicata, 2, 87-92.

Marcato G., Zabuski L., Silvano S. (2007) Capabilities of Continuous and Discontinuous Modelling of the Rock Slopes - a Landslide in the Carnian Alps (Italy) Using as an Example, Geophysical Research Abstracts, 9: 02371, European Geosciences Union.

Starfield A. M., Cundall P. A. (1988) Towards a Methodology for Rock Mechanics Modelling, International Journal of Rock Mechanics and Mining Sciences, 25, 99-106.

Zabuski L., Marcato G. (2005) Numerical Modelling of the Landslide Processes Using Discontinuous Approach, Proc. Int. Conf. "Mass Movement Hazard in Various Environments”, Polish Geological Institute Special Papers 20, Kraków, 119-124.

Zabuski L., Marcato G. (2014) Analysis of Deformation Processes of Slopes with Taking into Account Discontinuous Character of the Rock Mass (in Polish with an English summary), Przeglad Geologiczny, 62, 308-316. 
Zabuski L. (2019) Three-Dimensional Analysis of a Landslide Process on a Slope in Carpathian Flysch, Archives of Hydro-Engineering and Environmental Mechanics, 66 (1-2), 27-45.

Zabuski L., Wójcik A., Gil E., Mrozek T., Rączkowski W. (2009) Landslide Process in a Flysch Massif - Case Study of the Kawiory Landslide, Beskid Niski Mts. (Carpathians, Poland), Geological Quarterly, 53 (3), PGI, Warsaw, 317-332. 